\title{
The Effects of Daily Repeated Magnetic Field on S-Nitroso-N- acetyl-DL penicillamine Induced Hyperalgesia
}

Günlük olarak tekrarlanan manyetik alan uygulamasının-Nitroso-N-acetyl-DL
penicillamine tarafından indüklenen hiperaljezi üzerine olan etkisi

\author{
Ahmet Altun*, Mustafa Ergül, Ali Kemal Filiz, Mesut Parlak, Merve Ergül, Tijen \\ Kaya Temiz
}

Department of Pharmacology (Assist. Prof. A. Altun, MD, M. Parlak, MD, Prof. T. K. Temiz, MD), Department of Physiology (A. K. Filiz, MD), Cumhuriyet University School of Medicine, Department of Biochemistry (M. Ergül, MD), Department of Pharmacology (M. Ergül, MD), Cumhuriyet University School of Pharmacy, TR-58140 Sivas

\begin{abstract}
Aim. The treatment of pain has been one of the most important objectives of medicine. We aimed to investigate antinociceptive effects and mechanisms of magnetic field (MF) on the hyperalgesia produced by S-Nitroso N-acetyl penicillamine (SNAP). Method. Study has been made in two sections. In the first section, rats were divided four groups (six in each). The first group was determined as sham group and administrated $0.3 \mathrm{~mL}, 0.9 \% \mathrm{NaCl}$ intraperitoneally (i.p) before assessing tail flick latencies (TFLs) (Sham group). In the second group, $2 \mathrm{mg} / \mathrm{kg}$ SNAP administrated i.p. and TFLs were assessed at the same time points with first group (SNAP group). In the third group, rats were repeatedly exposed to MF for 6 consecutive days (MF group). In the fourth group, SNAP was administrated i.p everyday shortly before MF exposure (SNAP+MF group). In the second section, animals divided to the same groups with the first section. Same procedures have been performed with the first section groups and blood samples were collected to determine plasma levels of $\beta$-endorphin and substance P. Results. SNAP $(2 \mathrm{mg} / \mathrm{kg})$ produced hyperalgesic effect with i.p. administration. MF application (5 $\mathrm{mT}$ and $165 \mathrm{~min}$ per day) produced a strong antinociception in Days 3 and 4. Tail flick values of SNAP+MF in Days 3 and 4 were found to be significantly low as compared to MF and Sham groups. In SNAP group, substance P levels were found to be significantly high. Plasma $\beta$-endorphin levels in MF and SNAP+MF groups were significantly high as compared to the Sham group. Conclusion. MF may be an alternative antinociceptive approach for pain treatment. There is need for further studies to overcome the tolerance to antinociceptive effects of MF.
\end{abstract}

Keywords: Hyperalgesia, magnetic field, snap, substance p, $\beta$-endorphin, tail flick

\section{Özet}

Amaç. Ağrı tedavisi tıbbın en önemli hedeflerinden biridir. Bu araştırmada manyetik alan uygulamasının S-Nitroso N-acetyl penicillamine (SNAP) tarafından oluşturulan ağrı üzerindeki etkilerini ve etki mekanizmasını araştırmayı amaçladık. Yöntem. Çalışma iki kısım olacak şekilde tasarlandı. Birindi kısımda hayvanlar her birinde altı hayvan olacak şekilde 4 gruba bölündü. Birinci grup sham grubu olarak belirlendi ve bu hayvanlara $0,3 \mathrm{~mL} \% 0,9 \mathrm{NaCl}$ tail flick latensleri ölçülmeden once uygulandı. İkinci gruba (SNAP grubu) $2 \mathrm{mg} / \mathrm{kg}$ SNAP i.p. olarak enjekte edildi ve sham grubu ile aynı zaman noktalarında tail flick ölçümleri yapıldı. Üçüncü grup (MF grubu) tekrarlayan altı gün boyunca manyetik alana maruz bırakıldı. Dördüncü grupta (SNAP+MF) hayvanlara manyetik alan uygulaması yapılmadan hemen önce $2 \mathrm{mg} / \mathrm{kg}$ SNAP i.p. olarak uygulandı. Çalışmanın ikinci kısmında ratlardan kan örnekleri alınarak kanlarında supstance $p$ ve B-endorfin seviyelerine ELISA yöntemi ile bakıldı. Bulgular. SNAP (2 mg/kg) anlamlı bir hiperaljezi meydana getirerek tail flick latenleslerini kısalttı. Manyeteik alan uygulaması (5 mT ve 165 dakika/gün) özellikle 3. ve 4. günlerde anlamlı bir analjezi meydana getirdi. SNAP grubunda substance $\mathrm{p}$ seviyeleri yüksek bulunurken, manyetik alan grubunda B-endorfin seviyelerinin yüksek olduğu tespit edildi. Sonuç. Bu sonuçlar manyetik alan uygulamasının ağrı tedavisinde alternatif bir yaklaşım olabileceğini göstermektedir. Fakat bu yöntemin kullanılabilmesi için gelişen toleransın üstesinden gelmenin yollarının bulunması ve bunun içinde ileri araştırmalara gereksinim vardır.

Anahtar sözcükler: Hiperaljezi, manyetik alan, snap, p maddesi, $\beta$-endorfin, tail flick 
Geliş tarihi/Received: December 10, 2013; Kabul tarihi/Accepted: September 12, 2014

\section{*Corresponding author:}

Dr. Ahmet Altun, Farmakoloji Anabilim Dalı, Cumhuriyet Üniversitesi Tıp Fakültesi, TR-58140 Sivas. E-mail: md.ahmetaltun@gmail.com

\section{Introduction}

Pain is defined as an unpleasant sensory and emotional experience that accompanies actual or potential tissue damages [1]. Pain is now considered as a multidimensional public problem that detrimentally affects the individual physical and psychological aspects of life, daily activities and work [2,3]. Activation of NMDA glutamate receptor, production of nitric oxide (NO), and enhanced release of substance $\mathrm{P}$ and calcitonin gene related peptide (CGRP) from primary afferents are key events in pain perception and central hyperexcitability [4].

Nitric oxide, a free radical gas, is now widely suggested as being an important biological messenger in either the peripheral or the central nervous system [5]. Considerable evidence indicates that nitric oxide (NO) plays an important role in central and peripheral modulation of nociception [6]. A role of NO in nociceptive signaling was initially based on the localization of neuronal NOS in the superficial dorsal horn and intermediolateral cell column [7]. The most used NOS inhibitor, NG-nitroarginine-L-methyl ester (LNAME) induces antinociception in several rat pain models follawing intracebrovetricular [8], intraperitoneal [9], intravenous [10], or intrathecal administiration.

A lot of studies suggest a complex role for NO in that both pro- and anti-nociceptive effects have been found. A pro-nociceptive role for NO in the periphery is supported by a number of findings. For example, in humans, NO evokes pain when administered into paravascular tissue or isolated cutaneous veins [11], and the NO/cGMP cascade mediates the inflammatory pain induced by bradykinin [12]. Also Intrathecal injection of Larginine a precursor of NO, and NO-releasing compounds, sodium nitroprusside (SNP) or hydroxylamine also produced hyperalgesia in the tail-flick test and the formalin pain model [13-16]. These data indicate that the NO/cGMP signaling pathway contributes to spinal hyperalgesia via a cGMP-dependent mechanism. In contrast, other studies provide evidence that the NO/cGMP cascade exerts peripheral anti-nociceptive effects. These include inhibition of the inflammatory pain induced by PGE2 [17] and mediation of the anti-nociceptive actions of a number of peripherally acting analgesic agents such as morphine and nonsteroidal anti-inflammatory drugs (NSAIDs) [18].

Although, S-Nitroso-N-acetyl-DL-penicillamine (SNAP) is a well known NO donor, up to the present study, most work on SNAP has not focused on nociception. The effects of SNAP on nociception are unclear. It was showed that SNAP can prevent the inflammatory hyperalgesia produced by PGE2 when applied intraplantary [19]. After all, it is expected that SNAP may play role as a hyperalgesic agent at spinal level like other NO donors.

Electromagnetic fields spread throughout the planet producing interferences with biological systems $[20,21]$. Static, sinusoidal and specific pulsed magnetic fields have been shown to alter animal and human behaviors, such as directional orientation, learning, pain perception (nociception) and anxiety-related behaviors [22]. There has been growing evidence that magnetic fields (MF) have analgesic effects on animals [23]. Convincing evidence has emerged, both in animals and humans, that a number of cellular, physiological and behavioral activities can be affected by a more or less prolonged exposure to MFs [24]. In the light of these evidences, the main purpose of present study to investigate effects of daily repeated exposure of rats to the magnetic field on hyperalgesia which is produced by NO donor SNAP and try to explain possible mechanisms of this interaction. 


\section{Materials and methods}

\section{Animals}

Adult male Wistar albino rats weighing 180-200 gr were used in the present experiment. Animals were housed in standard laboratory conditions with free access to food and water. Rats were maintained at $23 \pm 1{ }^{\circ} \mathrm{C}$ and under pathogen-free conditions on a 12: 12 $\mathrm{h}$ dark/light cycle. All experiments were conducted during the light part of the cycle (8.00-14.00). The experiments conducted in the present study were approved by the Animal Research Committee of Cumhuriyet University.

\section{Testing antinociception}

Antinociception was assessed using the radiant heat tail-flick test (May TF 0703 Tailflick Unit, Commat, Ankara, Turkey). The time that animal required to display an aversive reaction, from when the heat irradiation began to the tail flick, was called the TFL. The basal level of nociception was measured on Day 0. Before each nociceptive test, each rat in random order was put into an epoxy tube to acclimate for $10 \mathrm{~min}$. The heat was generated by a $50 \mathrm{~W}$ lamp positioned below the tail, while the heat focused at a point $1 / 3$ distant from the tip of the tail. The infrared intensity was adjusted so that basal TFL occurred at $3.8 \pm 0.4 \mathrm{~s}$. Animals with a baseline TFL below 3.4 or above $4.2 \mathrm{~s}$ were excluded from further testing. A cut-off time of $10 \mathrm{~s}$ was set to avoid possible tail skin damage. TFLs were measured at $0,15,45,75,105,135$ and 165 min. Each TFL data point was a mean of two measurements per rat. Once the rat flicks its tail, the autostopwatch in the tail-flick apparatus will record the latency time. Any animal not responding after $10 \mathrm{~s}$ was excluded from the study. Data were expressed as second $(\mathrm{sec})$. During the measurement, the observer was blind regarding the exposure conditions.

\section{Experiment design and measurements of TFLS}

Study has been made in two sections. In the first section, rats were divided four groups (six in each). The first group was determined as sham group and administrated $0.3 \mathrm{~mL}$, $0.9 \% \mathrm{NaCl}(\mathrm{SF})$ intraperitoneally (i.p) shortly before assessing tail flick latencies (TFLs) at $0,15,45,75,105,135$ and 165 min (Sham group). Hence the animals of Sham group were put into the magnet for 10 minutes when coils were not energized before assessing tail flick latencies. In the second group, in order to determine hyperalgesic effect of $\mathrm{S}$ Nitroso-N-acetyl-DL-penicillamine (SNAP), $2 \mathrm{mg} / \mathrm{kg}$ SNAP dissolved in $0.5 \mathrm{~mL} 0.9 \%$ $\mathrm{NaCl}$, administrated i.p. and TFLs were assessed at the same time points with first group (SNAP group). S-Nitroso-N-acetyl-DL-penicillamine (SNAP) from Sigma (St. Louis, MO, USA) was prepared freshly and dissolved in distillated water on the day of the experiment. In the third group, in order to observe the effects of magnetic field (MF) on nociception, rats were repeatedly exposed to MF for 6 consecutive days, and the tail flick latencies (TFLs) were measured everyday at 0, 15, 45, 75, 105, 135 and $165 \mathrm{~min}$ (MF group). Rats were exposed MF for 165 min during the day. MF apparatus was set to run for $15 \mathrm{~min}$ on and $15 \mathrm{~min}$ off. TFLs were measured in these periods in which machine were not activated at $0,15,45,75,105,135$ and $165 \mathrm{~min}$. In the fourth group, in order to determine effects of MF on SNAP induced hyperalgesia, $2 \mathrm{mg} / \mathrm{kg}$ SNAP was administrated i.p everyday shortly before MF exposure and TFLs were measured at the same time points with third group (SNAP+MF group).

According to the results of Section 1 of the study, in Section 2, twenty four adult male Wistar albino rats weighing 180-200 g were used divided four groups (six in each). The same applications were applied for these four groups in the same manner with section one. In the first group, In order to determine basal plasma levels of substance $\mathrm{P}$ and $\beta$ endorphin, $0.3 \mathrm{~mL}$ SF was administrated i.p. and blood samples were collected by intracardiac puncture at 75 min after administration. 
In the second group, in order to determine substance $\mathrm{P}$ and $\beta$-endorphin plasma levels after SNAP administration, rats were sacrificed by cervical dislocation 75 min after SNAP injection and blood samples were collected by intracardiac puncture.

In the third group, in order to determine effects of MF on plasma levels of substance $\mathrm{P}$ and $\beta$-endorphin, rats were repeatedly exposed to MF for 4 consecutive days. At the day 4 , rats were sacrificed by cervical dislocation and blood samples were collected by intracardiac puncture.

In the last group, in order to determine effects of SNAP + MF combination on plasma levels of substance $\mathrm{P}$ and $\beta$-endorphin, $2 \mathrm{mg} / \mathrm{kg}$ SNAP was administrated i.p. every day shortly before MF exposure. Then rats were repeatedly exposed to MF for 4 consecutive days. At the day 4, rats were sacrificed by cervical dislocation and blood samples were collected by intracardiac puncture.

\section{Application of sinusoidal magnetic field}

The magnetic field was generated in a specially designed device that has a solenoid of $500 \mathrm{~mm}$ in length and $210 \mathrm{~mm}$ in diameter. The solenoid was fed by electricity current. The magnetic field intensity was measured as $\mathrm{B}=5 \mathrm{mT}$ every point the solenoid. This magnet was constructed by winding 1400 turns of an insulated soft copper wire, which was $1.4 \mathrm{~mm}$ in diameter on a fiber base. Electricity current $(50 \mathrm{~Hz})$ was passed through the device and a time relay was added into the system. Magnetic field intensity was measured by a digital teslameter (Phywe) with an axial Hall-effect probe.

Inside the solenoid and between the poles of the electromagnet, a cage $(40 \times 17 \times 13 \mathrm{~cm})$ made of Plexiglass was placed in the homogeneous magnetic field. Six experimental animals were placed, in turn, in this cage in order to expose them to the magnetic field. Animals were exposed to the magnetic field for $165 \mathrm{~min}$ per day. The alternating magnetic field was exposed on the rats for 15 minutes and it was halted for 15 minutes within every 165 minutes. There were periods in which MF machine was working and silent zones in which MF machine was not activated. Animals were exposed to magnetic field two groups (six in each) between 9: 00 and 11:45, respectively. The exposure was applied for 6 days. The preliminary experiments were performed; the temperature was kept constant by an air condition and tested with in the solenoid. The solenoid was always kept in a north-south direction, and its temperature was maintained constant at $23 \pm 1{ }^{\circ} \mathrm{C}$. Exposure was always applied in a separate room apart from that for the control group, and animals were exposed to electrical transient as the field turned on and off.

\section{Statistical analyses}

A non-parametric method of statistical analysis was used. Statistical significance of more than two groups was evaluated by Kruskal-Wallis test $(\mathrm{p}<0.05)$, followed by Dunnett's multiple test for individual comparisons. To compare two groups, Mann-Whitney U-test was used $(\mathrm{p}<0.05)$.

\section{Results}

Mean baseline (BL) latencies for control group in antinociception studies ranged $3.8 \pm 0.4$ s. $0.3 \mathrm{~mL}$ saline $(0.9 \%)$ administration in control animals did not alter BL responses during the experiments ( $>0.05)$. Intraperitoneal administration of SNAP $(2 \mathrm{mg} / \mathrm{kg})$ induced a significant reduction in the latency response compared with sham group $(p<0.05$ ), indicating development of hyperalgesia. Hyperalgesic effect started at $45 \mathrm{~min}$ after SNAP administration $(\mathrm{p}<0.05)$ and the maximal hyperalgesic effect occurred at 75 $\min (\mathrm{p}<0.05)$. TFL values began to increase $75 \mathrm{~min}$ after SNAP injection and reached to the same levels with sham group at 165 min (Figure 1). 


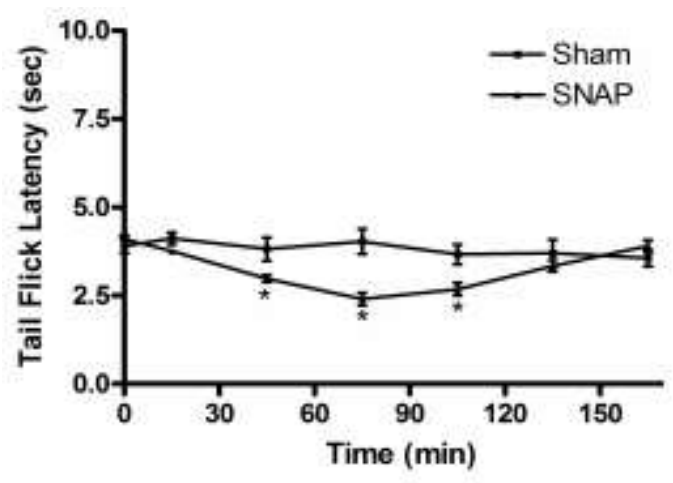

Figure 1. Hyperalgesic effects of intraperitoneal injection of SNAP. Rats were injected with 2 $\mathrm{mg} / \mathrm{kg}$ SNAP and nociceptive responses were assessed by Tail-flick test. * SNAP (2 mg/kg) produce a significant decrease in TFLs when compared to the Sham group $(p<0.05)$.

It was important to observe whether TFLs were changing in a day. So we did not just assess TFLs at the end of each experiment day. According to the experiment design, each animal was also assessed 7 times (at $0,15,45,75,105,135,165 \mathrm{~min}$ ) in a day while they were being exposed to MF. There was no significant change in TFLs which were assessed in the same day $(\mathrm{p}>0.05)$ (Figure 2).

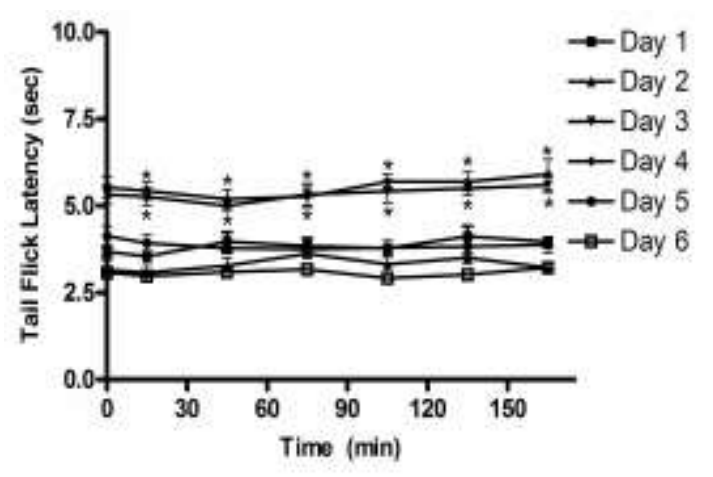

Figure 2. The effects of daily repeated MF on nociception during 6 days and comparison of TFLs which were assessed in the same day. * The TFLs increased significantly on Day 3 $(p<0.05)$ and Day $4(p<0.05)$ when rats exposed to MF for 6 days, 165 min per day.

During the 6 days of repeated exposure, TFLs values did not increase in the experimental groups compared with those of the sham groups on Day 1 and Day 2. On Day 3 and Day 4 , the values of TFLs increased significantly compared with those of sham animals $(\mathrm{p}<0.05)$. From Day 4, TFL values began to decrease, and on Day 6, TFL values decreased to the same level as that of the sham group (Figure 3 ).

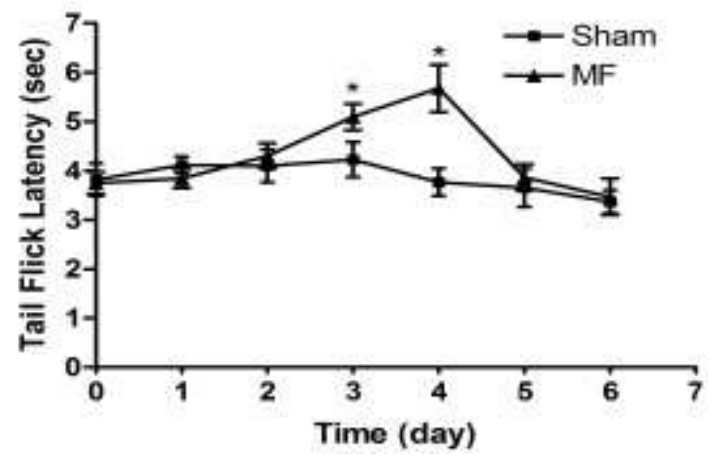

Figure 3. The effects of MF on SNAP induced hyperalgesia for 6 days application according to the days. $2 \mathrm{mg} / \mathrm{kg}$ SNAP was administrated i.p everyday before MF exposure and nociceptive responses were assessed by Tail-flick test. * The TFLs increased significantly on Day 3 (p<0.05) and Day 4 (p<0.05) when rats exposed to MF for 6 days, 165 min each day. 
In order to determine the effects of magnetic field on SNAP induced hyperalgesia, $2 \mathrm{mg} / \mathrm{kg}$ SNAP was administrated i.p. every day before MF exposure. Administration of SNAP $(2 \mathrm{mg} / \mathrm{kg})$ induced a reduction of the latency response compared with sham group and Day 4 of MF exposure alone $(\mathrm{p}<0.05)$. But TFLs of SNAP+MF Day 4 were significantly higher than administration SNAP alone $(\mathrm{p}<0.05)$ (Figure 4).

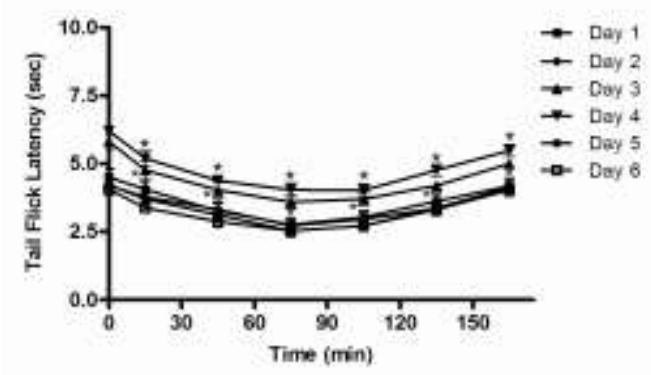

Figure 4. Comparison of TFLs of SNAP, MF Days 4 and SNAP+MF Days 4 . $* \mathbf{P}<0.05$ versus sham group. \# $P<0.05$ versus MF Day 4 and SNAP groups.

Figure 5 shows the levels of substance $\mathrm{P}$ in rat plasma. ELISA assay showed that administration of SNAP alone $(2 \mathrm{mg} / \mathrm{kg}$ ) increased the plasma levels of substance P when compared to the other groups $(\mathrm{p}<0.05)$.MF exposure or combination of MF with SNAP did not change the levels of substance $\mathrm{P}$ significantly compared to the sham group $(\mathrm{p}>0.05)$.

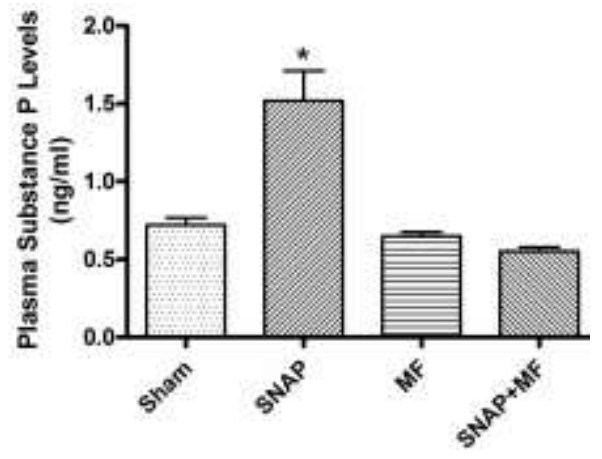

Figure 5. Plasma substance $P$ levels which were assessed by ELISA.* Plasma substance levels of SNAP group is significantly high when compared to Sham, MF and SNAP+MF groups $(\mathbf{p}<0.05)$.

Figure 6 shows the levels of $\beta$-endorphin in rat plasma. ELISA assay showed that both MF exposure and combination of MF with SNAP increased the plasma levels of $\beta$ endorphin when compared to the sham group and administration of SNAP alone $(\mathrm{p}<0.05)$. There is no significant difference between MF exposure and combination of MF with SNAP ( $p>0.05)$.

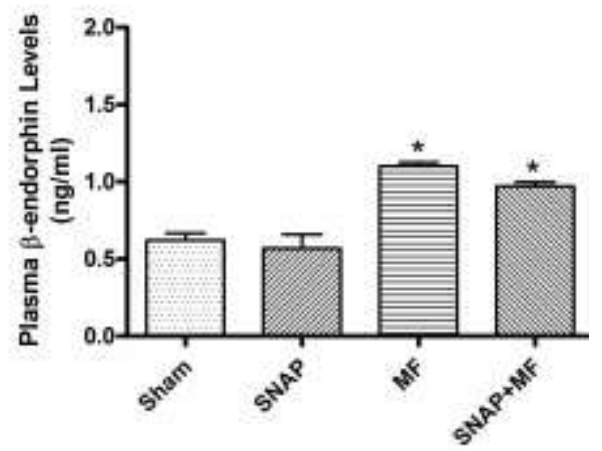

Figure 6. Plasma $\beta$-endorphin levels which were assessed by ELISA. * Plasma $\beta$-endorphin levels of MF and SNAP+MF groups are significantly high when compared to Sham and SNAP groups $(p<0.05)$. 


\section{Discussion}

In the spinal cord, considerable evidence has demonstrated that NO contributes to the development of hyperalgesia in models of acute and chronic pain [25]. Also, noxious stimulation increased NO synthase (NOS) expression [26] and cyclic guanosine monophosphate (cGMP) content [27] in the spinal cord. Our results were partially in line with these studies of Meller, Gebhart and Garry. The present study shows that SNAP $(2 \mathrm{mg} / \mathrm{kg})$ produces a significant hyperalgesia when administrated intraperitoneally. Hyperalgesic effect which has a time window started at $45 \mathrm{~min}$ and maximal hyperalgesic effect occurred at $75 \mathrm{~min}$ after SNAP administration. TFL values began to increase after $75 \mathrm{~min}$ and reached to the same level at that of sham group at $165 \mathrm{~min}$. These findings show that NO and SNAP as a NO donor may play a role in the cellular mechanism leading to spinal hyper excitability and increased pain perception.

Repeated daily MF exposure has effects on analgesia and can modify other behaviors [28]. Kavaliers and Ossenkopp also reported that a short repeated exposure of snail to weak $60 \mathrm{~Hz}$ MF had antinociceptive effects [29]. Bao and colleagues [30] showed that extremely low frequency magnetic field has antinociceptive effects in rats at Day 3 and 4 of 14 days repeated exposure. They used tail flick test at the end of each experiment day in order to determine the changes in nociception. In our study, distinctly from the study of Bao, rats were exposed to magnetic field for 6 days and TFLs were measured at 7 different time point in same day in order to determine the changes in nociception not only in different days but also during daytime period. In the present study, there was no change in nociception during daytime period. This finding may show that MF has no acute effect on nociception. In the first two days of our study, there was no significant change in nociception. This finding supports slow onset of antinociception produced by MF. Antinociceptive effects of MF exposure occurred at Day 3 and peaked at Day 4 and then decreased to the sham levels at Day 6. These results indicate that MF has an antinociceptive effect which has a "time window" with a maximum at Days 3 and 4. From Day 4, TFLs began to show a progressive decline. This may due to opioid tolerance, which is characteristic effect of repeated administrations of opiates [31].

In the first 2 days of SNAP+MF group, nociceptive effects of multipl administration of SNAP and MF were similar with SNAP group. At Days 3 and 4, there was significant antinociception when compared to administration of SNAP alone. But TFLs of Days 3 and 4 of SNAP+MF group were prominently lower than TFLs of MF group. This suggests that SNAP produces a hyperalgesic effect in SNAP+MF group, even at Days 3 and 4. But MF has overcome this hyperalgesic effect and total effect was determined as antinociception.

Substance $\mathrm{P}$ is involved in the regulation and modulation of acute and chronic pain transmission [32]. It is believed that substance $\mathrm{P}$ with other tachykinins is responsible for nociceptive transmission from peripheral to the central nerve system [33]. Substance $P$ occurs in small and medium-sized neurons of substantia gelatinosa of the spinal dorsal horn, as well as in peripheral and central endings of primary afferent fibers [34]. It is shown that substance $\mathrm{P}$ excites pain-transmission neurons in the dorsal horn [35]. When the neurotoxin capsaicin is used to destroy substance P-containing primary afferent neurons, animals become unresponsive to a variety of noxious stimuli [36]. In the light of these evidences, in the present study, we determined plasma substance P levels by using ELISA. In SNAP group, the plasma substance P levels increased significantly when compared to Sham, MF and SNAP+MF groups. There was no significant difference between Sham, MF and SNAP+MF groups. Our findings may show that substance $\mathrm{P}$ plays an important role in SNAP induced hyperalgesia and lowering substance P levels in SNAP induced hyperalgesia may be part of antinociceptive effect of MF. TFLs of SNAP+MF group were significantly low when compared to the MF group, although, there was no significant change in the plasma levels of substance P. This may show that there is an alternative mechanism in SNAP induced hyperalgesia aside from substance P. 
Numerous studies have indicated that the functional activity of endogenous opioid systems can be modified by the imposition of acute noxious stimulation [37-39]. By means of a variety of biochemical techniques, rats subjected to the chronic pain of polyarthritis were shown to exhibit pronounced selective, reversible, and contrasting alterations in the activity of the CNS and hypophyseal pools of P-endorphin (P-EP), methionine-enkephalin (ME), and dynorphin (DYN) [40, 41]. It was indicated that the degree of occupation of opioid receptors is enhanced under acute, stressful (noxious) stimulation [42]. Because of the close relationship between opioids and pain perception, in the present study, plasma $\beta$-endorphin levels were determined by ELISA. There was no significant change in the levels of $\beta$-endorphin in SNAP group when compared to the Sham group. In the MF and SNAP+MF groups, plasma $\beta$-endorphin levels were significantly high when compared to sham and SNAP group. There is no difference between MF and SNAP+MF groups. These findings may show that $\beta$-endorphin does not play a role in hyperalgesia produced by SNAP and plays an important role in antinociception produced by MF. From the Day 4, progressive decline in antinociception produced by MF may support the assertion of opioid tolerance.

In summary, the present study shows that; (1) SNAP produces a hyperalgesia in rats and substance P may play an important role in this hyperalgesia [2]. Stable levels of substance $\mathrm{P}$ in SNAP+MF group may show that there is an alternative mechanism in SNAP induced hyperalgesia aside from substance $\mathrm{P}$ [3]. MF exposure has an antinociceptive effect which has a "time window" and $\beta$-endorphin plays an important role in this antinociception [4]. From the Day 4, the progressive decline in TFLs may be related to opioid tolerance. If mechanism of this tolerance can be enlightened, MF may be an alternative choice in pain treatment.

\section{References}

1. IASP International Association for the Study of Pain. IASP Pain Terminology [IASP web site]. November 9, 2004. http://www.iasp-pain.org/terms-p.html. (Erişim tarihi: 12.09.2014).

2. Smith BH, Elliott AM, Chambers WA, Cairns SW, Hannaford PC, Penny K. The impact of chronic pain in the community. Fam Pract 2001; 18: 292-9.

3. Gureje O, Von Korff M, Simon GE, Gater R. Persistent pain and well-being: A World Health Organization Study in Primary Care. JAMA 1998; 280: 147-51.

4. Aimar P, Pasti L, Carmignoto G, Merighi A. Nitric Oxide-Producing Islet Cells Modulate the Release of Sensory Neuropeptides in the Rat Substantia Gelatinosa. Jour Neurosci 1998; 18: 10375-88.

5. Burlet S, Cespuglio R, Voltammetric detection of nitric oxide (NO) in the rat brain: Its variations throughout the sleep-wake cycle. Neurosci Lett 1997; 226: 131-5.

6. Luo ZD, Cizkova D. The role of nitric oxide in nociception. Curr Rev Pain 2000; 4: 459-66.

7. Saito S, Kidd GJ, Trapp BD, Dawson TM, Bredt DS, Wilson DA, Traystman RJ, Snyder SH, Hanley DF. Rat spinal cord neurons contain nitric oxide synthase. Neuroscience 1994; 59: 447-56.

8. Przewlocka B, Machelska H, Przewlocki R. Involvement of the nitric oxide pathway in nociceptive processes in the central nervous system in rats, Regul Pept 1997; 1: 75-6.

9. Hao JX, Xu XJ. Treatment of a chronic allodynia-like response in spinally injured rats: Effects of systemically administered nitric Nitric oxide directly activate calcium-dependent potassium chan- oxide synthase inhibitors. Pain 1996; 66: 313-9.

10. Yonehara N, Takemura M, Yoshimura M, Iwase K, Seo HG, Taniguchi N, Shigenaga Y. Nitric oxide in the rat spinal cord in Freund's adjuvant-induced hyperalgesia, Jpn J Pharmacol 1997; 75: 327-35. 
11. Holthusen H, Arndt JO. Nitric oxide evokes pain at nociceptors of the paravascular tissue and veins in humans. J Physiol 1995; 487: 253-8.

12. Holthusen $\mathrm{H}$. Involvement of the NO/cyclic GMP pathway in bradykininevoked pain from veins in humans. Pain 1997; 69: 87-92.

13. Kitto, KF, Haley JE, Wilcox GL. Involvement of nitric oxide in spinally mediated hyperalgesia in the mouse. Neurosci Lett 1992; 148: 1-5.

14. Meller ST, Dykstra C, Gebhart GF. Production of endogenous nitric oxide and activation of soluble guanylate cyclase are required for N-methyl-D-aspartateproduced facilitation of the nociceptive tail-flick reflex. Eur J Pharmacol 1992; 214: 93-6.

15. Meller ST, Pechman P.S, Gebhart G.F, Maves T.J. Nitric oxide mediates the thermal hyperalgesia produced in a model of neuropathic pain in the rat. Neuroscience 1992; 50: 7-10.

16. Coderre, TJ, Yashpal, K. Intracellular messengers contributing to persistent nociception and hyperalgesia induced by L-glutamate and substance $\mathrm{P}$ in the rat formalin pain model. Eur J Neurosci 1994; 6: 1328-34.

17. Durate ID, Lorenzetti BB, Ferreira SH. Peripheral analgesia and activation of the nitric oxide-cyclic GMP pathway. Eur J Pharmacol 1990; 186: 289-93.

18. Tonussi CR, Ferreira SH. Mechanism of diclofenac analgesia: Direct blockade of inflammatory sensitization. Eur J Pharmacol 1994; 251: 173-9.

19. Cunha FQ, Teixera MM, Ferreira SH. Br J Pharm 1999; 127: 671-8.

20. Panagopoulos DJ, Karabarbounis A, Margaritis LH. Mechanism for action of electromagnetic fields on cells. Biochem Biophys Res Commun 2002; 298: 95102.

21. Grassi C, D’Ascenzo M, Torsello A, Martinotti G,Wolf F, Cittadini A, Azzena GB. Effects of $50 \mathrm{~Hz}$ electromagnetic fields on voltage-gated $\mathrm{Ca}+2$ channels and their role in modulation of neuroendocrine cell proliferation and death. Cell Calcium 2004; 35: 307-15.

22. Sartucci F, Bonfiglio L, Del Seppia C, Luschi P, Ghione S, Murri L, Papi F. Changes in pain perception and pain-related somatosensory evoked potentials in humans produced by exposure to oscillating magnetic fields. Brain Res. 1997; 769: 362-6.

23. Martin LJ, Persinger MA. Thermal analgesia induced by 30 -min exposure to 1 $\mathrm{mT}$ burst-firing magnetic fields is strongly enhanced in a dose-dependent manner by the $\alpha 2$ agonist clonidine in rats. Neurosci Lett 2004; 366: 226-9.

24. Carpenter DO, Ayrapetyan S. Biological Effects of Electric and Magnetic Fields, Academic Press, San Diego, CA 1994; 1: 369.

25. Meller ST, Gebhart GF. Nitric oxide (NO) and nociceptive processing in the spinal cord. Pain 1993; 52: 127-36.

26. Lam HH, Hanley DF, Trapp BD, Saito S, Raja S, Dawson TM, Yamaguchi H. Induction of spinal cord neuronal nitric oxide synthase (NOS) after formalin injection in the rat hind paw. Neurosci Lett 1996; 210: 201-4.

27. Garry MG, Richardson JD, Hargreaves KM. Carrageenan induced inflammation alters the content of i-cGMP and i-cAMP in the dorsal horn of the spinal cord. Brain Res 1994; 646: 135-9.

28. Kavaliers M, Ossenkopp KP. Tolerance to morphine-induced analgesia in mice: Magnetic fields function as environmental specific cues and reduce tolerance development. Life Science 1985; 37: 1125-35.

29. Kavaliers M, Ossenkopp KP. Repeated naloxone treatments and exposures to weak $60 \mathrm{~Hz}$ magnetic fields have 'analgesic' effects in snail. Brain Research 1993; 620: 159-62.

30. Bao X, Shi Y, Huo X, Song T. A Possible involvement of $\beta$-endorphin, substance $\mathrm{P}$, and Serotonin in rat analgesia induced by extremely low frequency Magnetic Field. Bioelectromagnetics 2006; 27: 467-72.

31. Tiffany ST, Maude-Griffin PM. Tolerance to morphine in the rat: Associative and 
non-associative effects. Behav Neurosci 1988; 102: 434-43.

32. Rosen A, Zhang YX, Lund I, Lundeberg T, Yu LC. Substance P microinjected into the periaqueductal gray matter induces antinociception and is released following morphine administration. Brain Res 2004; 1001: 87-94.

33. Iversen LL. Substance P. Brit Med Bull 1982; 37: 277-82.

34. Nagy JI, Van Der Kooy D. Effects on neanatal capsaicin treatment on nociceptive thresholds in the rat. J Neurosci 1983; 3: 1145-50.

35. Randic M, Miletic V. Effect of substance $P$ in cat dorsal horn neurones activated by noxious stimuli. Brain Res 1977; 128: 164-9.

36. Yaksh TL, Farb DH, Leeman SE. Intrathecal capsaicin depletes substance P in the rat spinal cord and produces prolonged thermal analgesia. Science 1979; 206: 481-3.

37. Terman GW, Shavit Y, Lewis JW, Cannon JT, Liebeskind JC. Intrinsic mechanisms of pain inhibition: Activation by stress. Science 1984; 226: 1270-2.

38. Basbaum AI, Fields HL, Endogenous pain control systems: Brainstem spinal pathways and endorphin circuitry. Annu Rev Neurosci 1984; 7: 309-38.

39. Panerei IE, Martini A, Sacdrhdte P, Mantegazza P. K-Receptor antagonist reverses "non-opioid" stress-induced analgesia. Brain Res 1984; 304: 153-6.

40. Millan MJ, Millan MH, Pilcher CWT, CzJonkowski A, Herz A, Colpaert FC. Spinal cord dynorphin may modulate nociception via a K-opioid receptor in chronic arthritic rats. Brain Res 1985; 340: 156-9.

41. Millan MJ, Millan MH, Cztonkowski A, Hiillt V, Pilcher CWT, Herz A, Colpaert FC. A model of chronic pain in the rat: Response of multiple opioid systems to adjuvant-induced arthritis. J Neurosci 1986; 6: 899-906.

42. Millan MJ, Millan MH, Czkonkowski A, Pilcher CWT, Hiillt V, Colpaert FC, Herz A. Functional response of multiple opioid systems to chronic arthritic pain in the rat. Ann NY Acad Sci 1986; 467: 182-93. 